\title{
教育工学 $(\mathrm{ET})$ 研究会創立 50 周年を迎えて
}

中村 勝一

福島大学

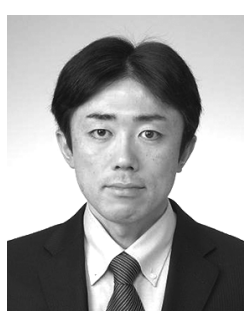

\section{1.はじめに}

教育工学研究会（ET研）は, 1967 年に, 本 会（当時, 電子通信学会）教育技術研究会と して設立され，50周年を迎える。古くは，欧 米で先行していた CAI (Computer-Assisted Instruction / Computer-Aided Instruction) や CMI (Computer-Managed Instruction) などに国内で 先駆的に取り組む研究者が集い，日本における 教育工学関連学協会の創出にも大きな影響を与 えた [1]. その後, コンピュータのパーソナル化, インターネット・各種メディアの普及などの転 換期を経て, 常に教育工学研究の最新動向が議 論される場として現在に至っている。本稿では, 本研究会の活動概況と活性化施策について報告 し，あわせて，50 周年を記念した事業について 紹介する。

\section{ET 研の活動概況}

ET 研は, 全国各地域で研究会を開催する方 針を貫き，年 9 回の定例研究会を開催している. また，理論，システム，実践研究まで，多様な立 場・視点での議論が展開されている $[2]$. 研究発 表件数についても, 少なくとも過去 15 年以上に わたり，年間 100 件以上の発表件数を得ている.

教育工学というと,「e-learningですか?」とい う反応が多くを占める状況が一時期認められた。 しかしこれは閉塞ではなく，実際には，一つのト レンドを象徴する現象であったと言える。現に， 研究動向を概観すると, Learning Analytics や学 習状況 ·過程の視覚化 (Big Data, Information Visualization), ITS: Intelligent Tutoring System ( $\mathrm{AI}$ 等)，新たな学習とその支援システムデザイ ン（Cloud 等）など，それぞれ教育工学研究と
して世界水準での最新動向について議論がなさ れてきた。それと同時に，情報科学の主要な研 究領域（各キーワードに付した括弧内）に影響 を受け・与える，熱い議論が展開されている。ま た一方で，例えば，近年の小学校へのプログラ ミング教育導入等に一端を垣間見られる論理的 思考能力育成という今日的動向に照らして, ET 研では，プログラミング教育が数十年来の主要 トピックであるなど，継続的議論の成果も認め られる，ET研は，長期にわたって研究会名称を 変更していない本会でも珍しい研究会の一つと なっているが，上述のとおり，幸いにして，教 育・学習を基軸・トリガとし, 貴重な研究イン タセクション的な場となっていることを誇りに 感ずるところである.

\section{3. 活性化の取組み}

$\mathrm{ET}$ 研では，本領域の活性化のための努力を 行っている。本稿では,「若手研究者育成」「情報 補償」の取組みについて紹介する。

\section{1 若手研究者育成}

有望な若手研究者の奨励を目的に，毎年定例 研究会の中で「若手フォーカス」の回を設定し, 優れた発表に対して研究奨励賞を授与している. この際，簡易的な推薦等によらず，専門委員が総 出で全ての対象発表を審査する努力を払ってい る。また, 通常活動している学会やバックグラン ドの垣根を越えて，学生を含めた若手研究者が 集う「教育システム若手の会」と連携し，ET研 として出展ブースを構えるなど，啓発と本会人 材への誘導に努めている，近年では，これらの取 組みの対象であった者が, ET研専門委員として 活躍するなど，嬉しい成果が得られ始めている． 


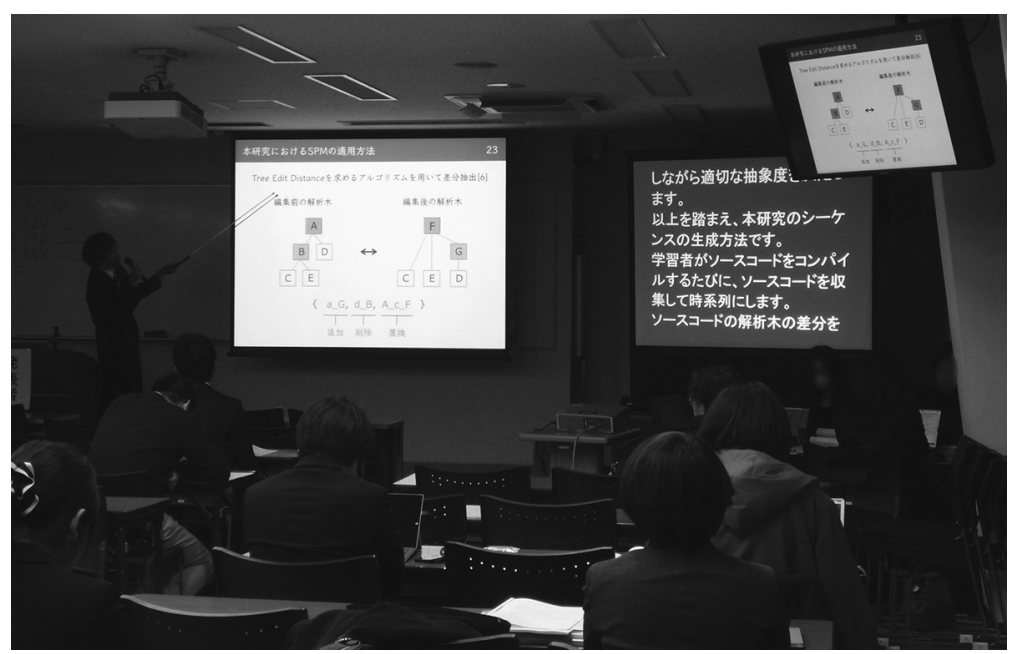

図 1. 定例研究会における情報補償の様子

\section{2 情報補償}

元来, 主要な研究トピックとして, 障害者教 育や特別支援教育を扱ってきたことに端を発し， 毎年度少なくとも 1 回の定例研究会では, 要約 筆記などの情報補償を実施している（図 1)，当 初は,「情報補償を実施している研究会がここに あります」というフラグシップ的な意図も強かっ たが，次第に浸透を経て，ET研の情報補償回を 狙って発表・参加して下さる研究者が複数生じ る嬉しい成果を得ている。

更に，当初は，上述した障害者教育・特別支 援教育をメインテーマとする回に情報補償をぺ アリング実施していたが，最近では，あえてそ れ以外のテーマ回に情報補償を実施する試みも 行っている, その結果, 文字どおり, 健常者と障 害を有する方が, 研究テーマに限定されず議論 する状況が得られるようになってきており， ET 研専門委員一同, 更なる努力に向けて大いにモ チベーションを得ている。

なお，2010年度から，それぞれの事業につい て, ISS 活動補助金を頂いていることが, これ らの成果を得る支えとなっている。この場をお 借りして, 深謝したい.

\section{50 周年記念行事}

本稿冒頭で触れたとおり, ET 研は, 50 周年
を迎えた。これを記念して，以下の取組みを実 施（一部は進行中）している.

- 50 周年記念研究会 · 祝賀会 [2]

（2017 年 11 月 11 日，於 ·上智大学 / 東京 グリーンパレス)

・和文論文誌 D 特集号「学びの変化と新しい 教育・学習支援技術特集」 [2]

・本会会誌での回想記事掲載 [3]

\section{5. おわりに}

本稿では，執筆時点の副委員長として，50 周 年を迎える ET 研の活動概況，活性化の取組み について報告した。

この先, 社会的要請, 情報技術の双方が大き く変化していく状況下において, ET研が, 新た な教育・学習実現の斢引役として, 更には, 広く 情報関連研究領域への新たな示唆・要求を発信す る研究会として, 益々発展することを期待する.

\section{参考文献}

[1] 岡本敏雄, “教育工学の歴史,”電子情報通信学 会知識ベース「知識の森」, S3 群 11 編, http:// www.ieice-hbkb.org/, 参照 Aug. 1, 2017.

[2] 電子情報通信学会 教育工学研究会, http:// www.ieice.org/iss/et/, 参照 Aug. 1, 2017.

[3] 清水康敬, “教育工学 50 年の歩み,” 信学誌, vol.98, no.12, pp.1091-1099, Dec. 2015. 